\title{
PERSEPSI BIDAN TERHADAP KUALIFIKASI PENDIDIKAN BIDAN DALAM UNDANG - UNDANG NO.4 TAHUN 2019 TENTANG KEBIDANAN
}

\author{
Ambar Dwi Erawati, Rinayati, Sriwahyuning \\ STIKes Widya Husada Semarang JI.Subali Raya No 12 Kelurahan Krapyak. Semarang (024)7612988 \\ email:ambarerawati@gmail.com
}

\begin{abstract}
ABSTRAK
Undang - undang kebidanan N0. 4 Tahun 2019 menyebutkan beberapa kriteria bidan berdasarkan kualifikasinya diantaranya; bidan vokasi, bidan akademisi, dan bidan profesi. Adanya kriteria kualifikasi pendidikan bidan dalam UU Kebidanan tentunya mempengaruhi perubahan kewenangan ditiap kualifikasi. Penelitian yang berjudul "Persepsi bidan terhadap perubahan kewenangan dalam rancangan Undang - undang kebidanan" menyebutkan bahwa mayoritas bidan mempunyai persepsi baik terhadap perubahan kewenangan. Tujuan penelitian ini adalah untuk mengetahui persepsi bidan di Wilayah ranting III IBI Kota Semarang terhadap kualifikasi pendidikan Bidan dalam UU Kebidanan. Desain Penelitian adalah studi Deskriptif dengan eknik pengambilan sampel secara insidental pada saat pertemuan IBI di Wilayah ranting III sebanyak 32 bidan. Hasil Penelitian menunjukkan persepsi setuju terhadap perubahan kualifikasi pendidikan bidan vokasi (81.3\%), tidak setuju (18.7\%) dan persepsi setuju terhadap pendidikan bidan akademik (71.9\%), tidak setuju (28.1\%) dan persepsi setuju dengan kualifikasi pendidikan profesi bidan (15.6\%) yang tidak (84.4\%). Kesimpulan penelitian ini adalah Bidan di wilayah Ranting III IBI Semarang sebagian besar memiliki persepsi setuju terhadap perubahan kualifikasi pendidikan bidan vokasi dan pendidikan bidan akademik dan sebagian besar persepsi yang tidak setuju terkait dengan kualifikasi pendidikan profesi bidan
\end{abstract}

Kata kunci : kebidanan;kualifikasi; pendidikan;undang-undang

\begin{abstract}
Obstetrics Act N0. 4 of 2019 mentions several midwife criteria based on their qualifications including; vocational midwives, academic midwives and professional midwives. The existence of midwife education qualification criteria in the Midwifery Act certainly affects changes in authority in each qualification. The study entitled "Perceptions of midwives on changes in authority in the draft midwifery law" states that the majority of midwives have good perceptions of changes in authority. The purpose of this study was to determine the perception of midwives in the Region III of Indonesian Midwifery Association of Semarang City on the midwifery education qualifications in the Midwifery Law. The research design was a descriptive study with incidental sampling techniques at the time of Indonesian Midwifery Association, with 32 midwives. The results showed perceptions of agreeing to changes in vocational midwifery education qualifications is $81.3 \%$, disagreeing $18.7 \%$ and perceptions agreeing with academic midwife education (71.9\%), disagreeing (28.1\%) and perceptions agreeing with midwife professional education qualifications (15.6\%) while there is $84.4 \%$ who didn't agree. The conclusion of this study is that most Midwives in the Region III of Indonesian Midwifery Association of Semarang City have the majority of perceptions of agreeing to changes in vocational midwifery education qualifications and academic midwife education and most of the disagreeing perceptions related to midwifery professional education qualifications
\end{abstract}

Keywords: law; midwifery;qualifications;education 


\section{LATAR BELAKANG}

Bidan adalah seseorang yang telah mengikuti program pendidikan bidan yang diakui di negaranya dan telah lulus dari pendidikan tersebut, serta memenuhi kualifikasi untuk didaftarkan (register) dan atau memiliki izin yang sah (lisensi) untuk melakukan praktik bidan.(ibi.or.id di akses 23 Januari 2018) Pendidikan bidan sudah ada sejak tahun 1851, dimana tenaga bidan di butuhkan untuk menolong masyarakat secara cuma-cuma. Pada tahun 1935-1938 dibuka pendidikan bidan dengan lulusan mulo (Setingkat SMP). Pada tahun 1950-1953 dibuka pendidikan bidan dari lulusan SMP atau usia minimal 17 th. Pada tahun 1954 dibuka pendidikan guru bidan, pada tahun 1970 dibuka pendidikan bidan dari lulusan SPR (Sekolah Pengatur Rawat). Pada Tahun 1989 dibuka pendidikan bidan dari lulusan SPK (Sekolah Perawat Kesehatan), pada tahun 1993 dibuka pendidikan bidan dari lulusan AKPER dan mulai tahun 1997 dibukapendidikan bidan dari SMA yang lulusannya adalah Ahli Madaya (Purwandari, Atik.2008)

Undang-Undang Kebidanan menyebutkan beberapa kriteria bidan berdasarkan kualifikasinya diantaranya; pendidikan akademisi, pendidikan vokasi dan pendidikan profesi. Di setiap kualifikasi pendidikan mempunyai tempat kewenangan yang berbeda. Dalam penelitian yang berjudul "Persepsi bidan terhadap perubahan kewenangan dalam rancangan Undang - undang kebidanan" menyebutkan bahwa mayoritas bidan mempunyai persepsi tidak baik terhadap perubahan tersebut. (Ambar Dwi Erawati, Persepsi bidan terhadap perubahan kewenangan dalam Draft Undang - undang kebidanan 2019, STIKES Widya Husada). Persepsi terhadap perubahan kewenangan belum tentu sama terhadap perubahan kualifikasi bidan.

Oleh karena itu menimbulkan pertanyaan bagi peneliti "Bagaimana persepsi bidan terhadap kualifikasi pendidikan bidan dalam UU Kebidanan?"

Tujuan penelitian ini adalah Untuk mengetahui persepsi bidan terhadap kualifikasi pendidikan Bidan dalam UU Kebidanan

\section{METODE}

Desain Penelitian yang dipakai dalam penelitian ini adalah studi Deskriptif. Variabel dalam penelitian ini yaitu persepsi bidan terkait dengan kualifikasi pendidikan bidan dalam UU Kebidanan. Teknik pengambilan sampel dalam penelitian ini adalah secara insidental pada saat pertemuan IBI di Wilayah ranting III. Pada saat pengambilan data jumlah bidan yang hadir dan digunakan sebagai sampel adalah 32 . Instrumen yang digunakan adalah kuesioner dalam bentuk pernyataan positif dengan skala likert, pengukuran dikategorikan dengan sikap positif apabila $t>t$ mean dan sikap negatif apabila $\mathrm{t}<\mathrm{t}$ mean

\section{HASIL}

\section{Persepsi Bidan terkait dengan Bidan berpendidikan D III Kebidanan adalah bidan Vokasi}

Undang-Undang Kebidanan no.4 tahun 2019 pada pasal 6 ayat 1 menyebutkan bahwa : Pendidikan vokasi sebagaimana dimaksud dalam Pasal 4 huruf $b$ merupakan program diploma tiga kebidanan. Berikut persepsi bidan terkait dengan Bidan berpendidikan D III Kebidanan adalah bidan Vokasi.

\section{Tabel 1 Persepsi Bidan terkait dengan Bidan berpendidikan D III Kebidanan adalah bidan Vokasi}

\begin{tabular}{lll}
\hline Kategori & Frekuensi & Persentase \\
\hline Setuju & 26 & $81,3 \%$ \\
Tidak Setuju & 6 & $18,7 \%$ \\
\hline
\end{tabular}

Berdasarkan tabel 1 diketahui bahwa sebagian besar atau 81,3\% (26 bidan ) setuju terhadap ketentuan bidan yang berpendidikan D III Kebidanan adalah bidan Vokasi, 18,7 \% (6 bidan) memiliki memiliki persepsi yang tidak setuju terhadap ketentuan bidan yang berpendidikan D III Kebidanan adalah bidan Vokasi. 
Persepsi Bidan Terkait dengan Pendidikan akademik Bidan sampai dengan Program sarjana Kebidanan, Magister dan Doktor. Undang-Undang Kebidanan no.4 tahun 2019 pada pasal 5 ayat 1 menyebutkan bahwa :

Pendidikan akademik sebagaimana dimaksud dalam Pasal 4 huruf a terdiri atas: program sarjana, program magister dan program doktor. Berikut persepsi bidan terkait isi pasal tersebut.

\section{Tabel 2 Persepsi Bidan Terkait dengan Pendidikan akademik Bidan sampai dengan Program sarjana Kebidanan, Magister dan Doktor.}

\begin{tabular}{lll}
\hline Kategori & Frekuensi & Persentase \\
\hline Setuju & 23 & $71,9 \%$ \\
Tidak Setuju & 9 & $28,1 \%$ \\
\hline
\end{tabular}

Berdasarkan tabel 2 diketahui bahwa sebagian besar atau 71,9 \% (23 bidan ) setuju terhadap ketentuan pendidikan bidan sampai dengan program sarjana, 28,1 \% (9 bidan) tidak setuju terhadap ketentuan ketentuan pendidikan bidan sampai dengan program sarjana.

\section{Persepsi Bidan Terkait dengan Pendidikan Profesi}

Undang-Undang Kebidanan no.4 tahun 2019 pada pasal 5 ayat 1 menyebutkan bahwa : Lulusan pendidikan akademik sebagaimana dimaksud, pada ayat (1) huruf a dapat melanjutkan program pendidikan profesi. Berikut persepsi bidan terkait isi pasal tersebut.

\section{Tabel 3 Persepsi Bidan Terkait dengan Pendidikan Profesi}

\begin{tabular}{lll}
\hline Kategori & Frekuensi & Persentase \\
\hline Setuju & 5 & $15,6 \%$ \\
Tidak Setuju & 27 & $84,4 \%$
\end{tabular}

Berdasarkan tabel 3 diketahui bahwa sebagian besar atau 84,4 \% (27 bidan ) memiliki tidak setuju terhadap ketentuan pendidikan harus profesi, dan sebanyak 15,6\% (5 bidan) setuju terhadap ketentuan bidan harus profesi.

\section{PEMBAHASAN}

Responden menyatakan setuju terhadap perubahan kualifikasi pendidikan bidan dalam Undang - undang kebidanan, hal tersebut sesuai dengan hasil penelitian yaitu Persepsi bidan terhadap ketentuan bidan yang berpendidikan D III Kebidanan adalah bidan Vokasi yaitu sebanyak 81,3\% (26) responden menyatakan setuju, persepsi responden terhadap ketentuan pendidikan bidan sampai dengan program sarjana sebnyak $71,9 \%$ (23) responden menyatakan setuju, persepsi responden terhadap ketentuan pendidikan bidan harus profesi tidak setuju sebanyak $84,4 \%$ (27).

Menurut Miftah Toha (2003;154) Faktor yang mempengaruhi persepsi faktor internal yaitu perasaan, sikap dan kepribadian individu, prasangka, keinginan atau harapan, perhatian(fokus), proses belajar, keadaan fisik, gangguan kejiwaan, nilai dan kebutuhan juga minat dan motivasi. Faktor eksternal adalah latar belakang keluarga, informasi yang diperoleh, pengetahuan dan kebutuhan sekitar, intensitas, ukuran, keberlawanan, pengulangan gerak, hal-hal baru dan familiar atau ketidak asingan suatu obyek.

Responden menginginkan adanya peningkatan dejat pendidikan bidan tidak hanya sampai dengan D III saja tapi sampai dengan sarjana.

Melihat sejarah perkembangan bidan di Indonesia, kualifikasi pendidikan bidan di Indonesia mengalami beberapa peubahan yang sifatnya perubahan adalah meningkat. Hasil penelitian ini menunjukkan persepsi bidan setuju bisa disebabkan karena komponen afektif karena adanya harapan, cita-cita dengan adanya peningkatan kualifikasi pendidikan akan meningkat juga mutu pelayanan kebidanan.

Faktor Eksternal yang mempengaruhi bidan terkait dengan persepsi yang baik terhadap kualifikasi pendidikan bidan adalah terkait dengan kebutuhan bidan.

Menurut Yuningsih dalam Penelitian "Pengembangan Kebijakan Profesi Bidan dalam Upaya Meningkatkan Pelayanan Kesehatan Ibu dan Anak" dimasa yang akan 
datang dibutuhkan tenaga kebidanan yang memiliki pengetahuan, ketrampilan dan perilaku yang unggul serta menjujung tinggi etika dan hukum kesehatan. Pemberian pelayanan kebidanan profesional hendaknya dilakukan oleh bidan professional menggantikan bidan vokasi(Yuningsih, R.2016)

Ada tiga jenis pendidikan tinggi yaitu akademik, vokasi dan profesi. Pendidikan Akademik merupakan pendidikan tinggi program sarjana, pascasarjana yang diarahkan pada penugasan dan pengembangan cabang ilmu pengetahuan dan teknologi. Pendidikan vokasi merupakan pendidikan tinggi diploma yang disiapkan untuk bekerja dengan keahliannya. Pendidikan profesi merupakan pendidikan tinggi setelah sarjana yang disiapkan untuk bekerja yang memerlukan keahlian khusus(Yuningsih, R.2016).

\section{KESIMPULAN DAN SARAN}

Bidan di wilayah Ranting III IBI Semarang sebagian besar memiliki persepsi setuju terhadap perubahan kualifikasi pendidikan bidan vokasi $(81.3 \%)$ dan pendidikan bidan akademik (71.9\%) dan sebagian besar persepsi yang tidak setuju terkait dengan kualifikasi pendidikan profesi bidan (84.4\%).

Bidan hendaknya selalu meningkatkan kualitasnya melalui pendidikan formal ataupun non formal agar tidak kalah dengan profesi lain. Organisasi profesi $\mathrm{IBI}$ selalu mengembangkan kebijakan - kebijakan yang meningkatkan kualitas anggota profesinya. Perlu adanya penelitian yang lebih mendalam terkait peraturan kebidanan, terkait pengaruh informasi, kebutuhan bidan yang memiliki kontribusi dalam menurunkan Angka Kematian Ibu.

\section{REFERENSI}

Azwar, S.(2005). Sikap Manusia Teori dan Pengukurannya. Pustaka Pelajar. Yogyakarta.

Dwi Erawati Ambar, dkk. (2017) Persepsi bidan terkait perubahan kewenangan dalam draft RUU kebidanan. STIKES Widya Husada : Semarang.

Fatimah, Meilia Siti (2009). Hubungan persepsi terhadap profesi bidan dengan motivasi belajar mahasiswa pendidikan D III kebidanan.UNS.Surakarta.

F.Marbun dan Moh Mahfud MD, (2006) PokokPokok Hukum Administrasi Negara, Liberty: Yogyakarta.

Miftah Toha.(2003). Perilaku Organisasi Konsep Dasar dan Aplikasinya. Grafindo Persada. Jakarta

Notoadmojo, S. Pendidikan Dan Perilaku Kesehatan. (2003). Rineka Cipta: Jakarta.

Becker, E. (2001, August 27). Prairie farmers reap conservation's rewards. The New York Times. $\quad$ Retrieved from http://www.nytimes.com.

IBI. (1999). Lima Puluh Tahun IBI. Jakarta: IBI

Philipus M. Hadjon, (2005), Pengantar Hukum Administrasi Indonesia, Gadjah Mada University Press: Yogyakarta.

Prajudi Atmosudirdjo, (1981), Hukum Administrasi Negara, Ghalia Indonesia: Jakarta.

Purwandari, Atik. 2008. Konsep Kebidanan: SEjarah dan Profesionalisme.EGC.Jakarta.

SF, Marbun, (2011), Peradilan Administrasi Negara dan Upaya Administratif di Indonesia, FH UII Press: Yogyakarta.

Ridwan HR, (2002), Hukum Administrasi Negara, .Raja Grafindo Persada: Jakarta.

Titik Triwulan Tutik( 2012) Pengantar Hukum Tata Usaha Negara, Prestasi Pustaka Publisher: Jakarta.

Yuningsih,Rahmi.(2016). Pengembangan Kebijakan Profesi Bidan Dalam Upaya Meningkatkan Pelayanan Kesehatan Ibu Anak. Jakarta. Pusat Penelitian Badan Keahlian DPR

RI. 